Int. J. Electrochem. Sci., 15 (2020) 10731 - 10744

\title{
Enhanced Photocatalytic Activity of Vertically-Aligned Transition Metal-Doped Zinc Oxide Nanorods Synthesized by a Facile Electrochemical Method
}

\author{
Shaochun Yuan ${ }^{1}$, Min Wang ${ }^{1, *}$, Bo $L v^{2, *}$ \\ ${ }^{1}$ Chongqing Engineering Laboratory of Environmental Hydraulic Engineering, Chongqing Jiaotong \\ University, Chongqing, 400074, PR China \\ ${ }^{2}$ Engineering Research Center for Sponge City Construction of Chongqing, Chongqing, 400020, PR \\ China \\ *E-mail: wangm@cqjtu.edu.cn (Min Wang) and haimiancq@163.com (Bo Lv)
}

doi: $10.20964 / 2020.11 .61$

Received: 7 July 2020 / Accepted: 15 September 2020 / Published: 30 September 2020

The present work aims to study the photocatalytic activity of vertically-aligned $\mathrm{Mn}_{\mathrm{x}} \mathrm{Zn}_{1-\mathrm{x}} \mathrm{O}$ nanorods (x $=0,0.05,0.1,0.15$ and 0.2 ) by optical, electrochemical analyses and rhodamine $\mathrm{B}(\mathrm{RhB})$ degradation. Therefore, high density of $\mathrm{Mn}_{\mathrm{x}} \mathrm{Zn}_{1-\mathrm{x}} \mathrm{O}$ nanorods array were electrodeposited on ITO coated glass and GCE substrates. The XRD analysis indicated the wurtzite structure for $\mathrm{ZnO}$ and confirmed formation of $\mathrm{Mn}_{2} \mathrm{O}_{3}$ impurity phase in $\mathrm{Mn}_{\mathrm{x}} \mathrm{Zn}_{1-\mathrm{x}} \mathrm{O}$ samples. Optical study showed the edges of absorption spectra were blue-shifted with increasing $\mathrm{Mn}$ concentrations. The photocatalytic performance of $\mathrm{Mn}_{\mathrm{x}} \mathrm{Zn}_{1-}$ ${ }_{x} \mathrm{O} / \mathrm{GCE}$ was studied through electrochemical determination of Gallic acid and RhB degradation. Amperometric analysis exhibited that the electrocatalytic current density was increased with increasing the dopant concentration in $\mathrm{ZnO}$ nanorods. The photoelectrocatalytic capability was studied in dark and under light irradiation conditions. Results showed that the stability, detection limit, sensitivity and photocatalytic activity of $\mathrm{Mn}_{\mathrm{x}} \mathrm{Zn}_{1-\mathrm{x}} \mathrm{O} / \mathrm{GCE}$ were improved remarkably by doping $\mathrm{Mn}$ in $\mathrm{ZnO}$ lattice. Furthermore, $\mathrm{Mn}_{\mathrm{x}} \mathrm{Zn}_{1-\mathrm{x}} \mathrm{O}$ nanorods array displayed a desirable performance on $\mathrm{RhB}$ photocatalytic degradation.

Keywords: Photocatalytic activity; $\mathrm{Mn}_{\mathrm{x}} \mathrm{Zn}_{1-\mathrm{x}} \mathrm{O}$ nanorods; Electrodeposition technique; Amperometric analysis; RhB degradation

\section{$\underline{\text { FULL TEXT }}$}

(C) 2020 The Authors. Published by ESG (www.electrochemsci.org). This article is an open access article distributed under the terms and conditions of the Creative Commons Attribution license (http://creativecommons.org/licenses/by/4.0/). 